\title{
Multi-element analysis and differentiation of Chilean wines using mineral composition and multivariate statistics
}

\author{
Yaneris Mirabal-Gallardoํ, María A. Caroca-Herrera², Luis Muñoz ${ }^{3}$, \\ Macarena Meneses ${ }^{3}$, and V. Felipe Laurie ${ }^{2}$ \\ ${ }^{1}$ Universidad Autónoma de Chile, Faculty of Engineering, Institute of Applied Chemistry. 5 Poniente 1670, \\ Talca, Chile. \\ ${ }^{2}$ Universidad de Talca, School of Agricultural Sciences. 2 Norte 685, Talca, Chile. \\ ${ }^{3}$ Chilean Nuclear Energy Commission, Amunátegui 95, Santiago, Chile.
}

\begin{abstract}
Y. Mirabal-Gallardo, M. A. Caroca-Herrera, L. Muñoz, M. Meneses, and V. F. Laurie. Multi-element analysis and differentiation of Chilean wines using mineral composition and multivariate statistics. 2018. Cien. Inv. Agr. 45(2): 181-191. The concentration of seventeen metal elements was analyzed in 130 commercial samples of Chilean wines, using flame atomic absorption spectroscopy (AAS) and inductively coupled plasma-mass spectrometry (ICP-MS). The elements analyzed were within the usual concentration ranges previously reported in other wine regions (for example: Fe, $2.08 \pm 0.99 \mathrm{mgL}^{-1} ; \mathrm{Zn}, 0.71 \pm 0.44 \mathrm{mg} \mathrm{L}^{-1}$; K, $788 \pm 219 \mathrm{mg}$ $\mathrm{L}^{-1}$; and $\left.\mathrm{Na}, 14.62 \pm 8.6 \mathrm{mg} \mathrm{L}^{-1}\right)$. When the metal content of the samples was compared among geographic areas, significant differences in the concentration of $\mathrm{K}, \mathrm{Na}, \mathrm{Mn}, \mathrm{Mg}, \mathrm{Zn}$, and $\mathrm{Cr}$ were observed $(p \leq 0.05)$. Moreover, principal component and linear discriminant analyses, used to discriminate wines according to geographic area, obtained adjustments above $90 \%$ for white wines and over $70 \%$ for red wines.
\end{abstract}

Keywords: AAS, classification, element, ICP-MS, metal, multivariate statistics, wine.

\section{Introduction}

Mineral elements have an important influence on the quality of grapes and wines. Some of these elements are essential for the proper metabolic function of vines and should be added as nutrients if their natural concentration is limited (Iland and

Received Oct 17, 2017. Accepted Jun 20, 2018. Corresponding author: flaurie@utalca.cl
Coombe, 1988). In musts and wines, the composition of metals influences the $\mathrm{pH}$, ion balance, yeast activity, color, and the chemical and oxidative stability of the product (Pohl, 2007; Tariba, 2011).

The analysis of these constituents is used to assess the presence of contaminants, verify their concentration for winemaking purposes (e.g., metal haze formation), and to ensure that the regulatory requirements for commercialization are met. Similarly, this information has been 
used to verify the wine's authenticity based on the correlation between metal composition and geographic origin (Arvanitoyannis et al., 1999; Zou et al., 2012; Versari et al., 2014).

To date, a number of studies have analyzed wine provenance based on metal composition (Castiñeira et al., 2004; Coetzee and Vanhaecke, 2005; Angus et al., 2006; Zou et al., 2012; Aceto et al., 2013; Alkis et al., 2014). In some of these studies, the authors have found a good correlation between the content of metals in the soil, grapes and wine (Coetzee et al., 2005; Pohl, 2007; Zou et al., 2012), allowing for a good degree of sample differentiation when a large number of metal elements and wine samples were analyzed (Coetzee et al., 2014; Paneque et al., 2017). However, other reports have revealed that certain viticulture and winemaking practices may alter the content of metals (e.g., vineyard fertilizers, plant protection products, winemaking aids such as bentonite, etc.), thus limiting the ability to find correlations between the mineral content of the soils and those of finished wines (Almeida and Vasconcelos, 2003; Catarino et al., 2007; Aceto et al., 2013; Hopfer et al., 2015).

In the case of Chilean wines, only one attempt has been made to characterize the content of metals (Laurie et al., 2010). In that study, seventy-five wine samples were analyzed for $\mathrm{K}, \mathrm{Mg}, \mathrm{Ca}, \mathrm{Na}$, $\mathrm{Fe}$ and $\mathrm{Zn}$, with most of them being within the usual concentration ranges previously reported for other wine regions. Additionally, it was observed that wines produced near coastal areas had a much higher content of $\mathrm{Na}$ than those produced in other viticultural areas. Aside from that study, we are not aware of any attempts to characterize the composition of a wider range of elements or to differentiate Chilean wines according to their metal composition. Therefore, the aims of this work were to study the concentration of seventeen macro and microelements in Chilean wines and to use multivariate statistics to identify discriminating elements that could allow for us to group samples according to geographic origin.

\section{Materials and Methods}

\section{Wine samples}

The study included 130 bottles of commercial wines representing six varieties, two viticultural regions, six subregions, four zones/areas (Figure 1), and three different vintages (Table 1). These samples were donated by different wineries or purchased from local stores and were selected based on a similar price range (approximately US\$ 5 to 10). The alcohol strength of the samples varied between 12.5 and $14 \%$ for white wines and 13 to $14.5 \% \mathrm{v} / \mathrm{v}$ for reds. Their $\mathrm{pH}$ ranged from 2.99 to 3.44 for white wines and 3.04 to 3.68 for reds (Table a, supplemental information).

\section{Reagents and solutions}

All solutions were prepared using ultra-pure water, obtained from a Millipore system (Bedford, MA, USA). Nitric acid $\left(\mathrm{HNO}_{3}, 65 \%\right)$ and hydrogen peroxide $\left(\mathrm{H}_{2} \mathrm{O}_{2}, 30 \%\right)$ were purchased from Sigma Aldrich (Darmstadt, Germany), and Lanthanum oxide $\left(\mathrm{La}_{2} \mathrm{O}_{3}\right)$ was bought from Merck (Darmstadt, Germany). The calibration curves for $\mathrm{K}, \mathrm{Na}, \mathrm{Mg}, \mathrm{Ca}, \mathrm{Fe}, \mathrm{Zn}, \mathrm{Cu}$ and $\mathrm{Mn}$ were prepared from certified individual commercial solutions of $1000 \mathrm{mg} \mathrm{L}^{-1}$ as explained below (Spex Industries Inc., Edison, NJ, USA). Additionally, a Certipur ${ }^{\circledR}$ ICP multi-element standard solution of $1000 \mathrm{mg} \mathrm{L}^{-1}$ obtained from Merck was used to develop the calibration curves for the analyses of microelements.

Glassware was cleaned by soaking in $10 \% \mathrm{v} / \mathrm{v}$ $\mathrm{HNO}_{3}$ solution for $24 \mathrm{~h}$ and rinsed at least three times with ultra-pure water. Then, the material was dried and stored in a class-100 laminar flow hood.

\section{Calibration curves}

Five-point calibration curves were prepared for each of the seventeen metals studied (i.e., K, Na, 

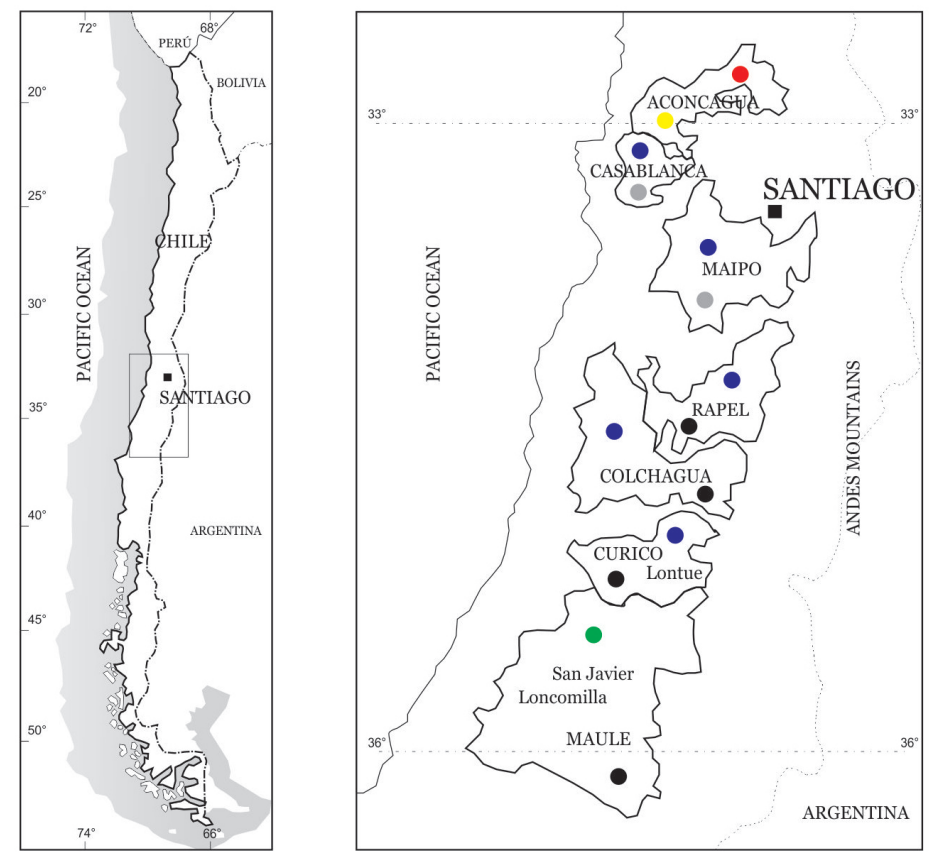

\section{Soil and climate by geographical area}

Soil:

- Silt-fluvial filling

- Alluvial origin

- Alluvial and volcanic origin

Climate:

Meditarranean temperate

Warm temperate

- Mediterranean subhumid

Figure 1. Wine regions of Chile.

Table 1. Wine samples used for the analysis of mineral composition.

\begin{tabular}{|c|c|c|c|c|c|}
\hline Wine type & Viticultural Region & Subregion & Zone/area & $\begin{array}{c}\text { Number of samples } \\
\text { and varieties }\end{array}$ & Vintages \\
\hline White & Aconcagua & Aconcagua & - & $2 \mathrm{Ch}, 2 \mathrm{Sb}$ & 2013 \\
\hline \multirow[t]{7}{*}{$(n=39)$} & & Casablanca & - & $3 \mathrm{Ch}, 2 \mathrm{Sb}$ & 2011-2013 \\
\hline & Central Valley & - & - & $5 \mathrm{Ch}, 4 \mathrm{Sb}$ & $2011-2013$ \\
\hline & & Rapel & Colchagua & $1 \mathrm{Sb}, 2 \mathrm{Vi}$ & 2013 \\
\hline & & Curicó & - & $1 \mathrm{Ch}, 3 \mathrm{Sb}$ & $2012-2013$ \\
\hline & & & Lontué & $1 \mathrm{Ch}, 1 \mathrm{Sb}$ & 2012-2013 \\
\hline & & Maule & - & $2 \mathrm{Ch}, 7 \mathrm{Sb}$ & $2012-2013$ \\
\hline & & & $\begin{array}{l}\text { Loncomilla/ } \\
\text { San Javier }\end{array}$ & $2 \mathrm{Ch}, 1 \mathrm{Sb}$ & 2013 \\
\hline Red & Aconcagua & Aconcagua & - & $1 \mathrm{CS}, 1 \mathrm{Cr}, 1 \mathrm{Me}, 1 \mathrm{Sy}$ & 2012 \\
\hline \multirow[t]{8}{*}{$(n=91)$} & Central Valley & - & - & $\begin{array}{l}8 \mathrm{CS}, 3 \mathrm{Cr}, 7 \mathrm{Me} \\
1 \mathrm{Ma}, 1 \mathrm{Pn}, 1 \mathrm{Cf}\end{array}$ & 2011-2013 \\
\hline & & Maipo & - & $3 \mathrm{CS}, 1 \mathrm{Cr}$ & 2011-2013 \\
\hline & & Rapel & - & $3 \mathrm{CS}, 3 \mathrm{Me}$ & 2011-2013 \\
\hline & & & Colchagua & $3 \mathrm{CS}, 6 \mathrm{Cr}, 2 \mathrm{Me}, 3 \mathrm{Sy}$ & 2011-2013 \\
\hline & & Curicó & - & $5 \mathrm{CS}, 3 \mathrm{Me}, 1 \mathrm{Sy}, 1 \mathrm{Cf}$ & $2010-2013$ \\
\hline & & & Lontué & $1 \mathrm{CS}, 2 \mathrm{Cr}, 1 \mathrm{Sy}, 1 \mathrm{Cf}$ & $2010-2012$ \\
\hline & & Maule & - & $\begin{array}{l}5 \mathrm{CS}, 7 \mathrm{Cr}, 4 \mathrm{Me} \\
2 \mathrm{Sy}, 3 \mathrm{Ma}, 2 \mathrm{Pn}\end{array}$ & $2011-2013$ \\
\hline & & & $\begin{array}{l}\text { Loncomilla/ San } \\
\text { Javier }\end{array}$ & $\begin{array}{c}1 \mathrm{CS}, 1 \mathrm{Me} / \\
1 \mathrm{CS}, 1 \mathrm{Cr}, 1 \mathrm{Sy}\end{array}$ & 2012 \\
\hline
\end{tabular}

Where: Ch, Chardonnay; Sb, Sauvignon blanc; Vi, Viognier; CS, Cabernet Sauvignon; Cr, Carmenére; Me, Merlot; Sy, Syrah; Ma, Malbec; Cf, Cabernet franc; Pn, Pinot noir. 
$\mathrm{Ca}, \mathrm{Zn}, \mathrm{Cu}, \mathrm{Fe}, \mathrm{Mg}, \mathrm{Mn}, \mathrm{Ni}, \mathrm{Cr}, \mathrm{Al}, \mathrm{Pb}, \mathrm{Cd}, \mathrm{Hg}$, $\mathrm{Se}, \mathrm{Co}$ and $\mathrm{Sn}$ ). For the atomic absorption spectroscopy (AAS) analyses, they were prepared from certified standard solutions of $1000 \mathrm{mg} \mathrm{L}^{-1}$ of each metal. The concentration ranges covered for each calibration curve were as follows: $\mathrm{Ca}, 1-25 \mathrm{mg} \mathrm{L}^{-1}$; $\mathrm{Mg}, 0.25-5 \mathrm{mg} \mathrm{L}^{-1}$; K, 2-20 mg L-1; Na, 1-10 mg $\mathrm{L}^{-1}$, Mn, 1-6 mg L ${ }^{-1}, \mathrm{Cu}, 0.5-5 \mathrm{mg} \mathrm{L}^{-1}, \mathrm{Fe}, 1-10 \mathrm{mg}$ $\mathrm{L}^{-1}$, and $\mathrm{Zn}, 0.5-3 \mathrm{mg} \mathrm{L}^{-1}$. Before measuring the macroelements $(\mathrm{Ca}, \mathrm{Mg}, \mathrm{K}$ and $\mathrm{Na})$ in the AAS, a 1:10 $\mathrm{v} / \mathrm{v}$ dilution of the samples was performed with $\mathrm{La}_{2} \mathrm{O}_{3}\left(1.1 \mathrm{~g} \mathrm{~L}^{-1}\right.$ solution). Conversely, $\mathrm{Mn}$, $\mathrm{Cu}, \mathrm{Fe}$ and $\mathrm{Zn}$ were determined with no dilution because of their low concentration.

The inductively coupled plasma-mass spectrometry (ICP-MS) analyses were based on the methodology reported by Aceto and collaborators (Aceto et al. 2013). The certified standard solution was a mixture of $5 \% \mathrm{HNO}_{3}$ solution (w/v) with the following additions: $10.0 \mathrm{mg} \mathrm{L}^{-1}$ for $\mathrm{Ca}, \mathrm{Cd}, \mathrm{Cr}, \mathrm{Fe}, \mathrm{Na}, \mathrm{Ni}, \mathrm{Pb}, \mathrm{Se}$, and $\mathrm{Zn}$; $10.1 \mathrm{mg} \mathrm{L}^{-1}$ for $\mathrm{Al}, \mathrm{Co}, \mathrm{Cu}, \mathrm{Mn}, \mathrm{Rb}$, and $\mathrm{Sr}$; and $9.9 \mathrm{mg} \mathrm{L}^{-1}$ for $\mathrm{Hg}, \mathrm{K}$, and $\mathrm{Mg}$. From this solution, a calibration curve was prepared with the following concentration points: $0.0002,0.0005,0.001,0.003$, $0.007,0.01,0.03,0.05,0.07$, and $0.1 \mathrm{mg} \mathrm{L}^{-1}$, using nitric acid (Suprapur $\left.{ }^{\circledR}\right)$ for dilution $(5 \% \mathrm{w} / \mathrm{v})$. The calibration curves obtained had coefficients of determination, $\mathrm{R}^{2}$, ranging between 0.997 and 0.999 .

\section{Wine analyses}

Once opened, the wine from each bottle was subjected to microwave-assisted acid digestion in order to eliminate organic interfering compounds (Alk1s, et al., 2014; Grindlay, et al., 2009). Five mL of wine, $3 \mathrm{~mL}$ of $65 \% \mathrm{HNO}_{3}$ and $1.5 \mathrm{~mL}$ of $\mathrm{H}_{2} \mathrm{O}_{2}$ $30 \%$ were placed in $55 \mathrm{~mL}$ Teflon $\AA$ tubes (MARS Xpress, Matthews, NC, USA). The samples were manually shaken for approximately 10 seconds and left to rest for $24 \mathrm{~h}$ before proceeding with the microwave-assisted heating program, which included a ramp time of 5 minutes going from 20 to $175^{\circ} \mathrm{C}$ with a 3 min hold time, followed by a 5 min ramp from 175 to $30^{\circ} \mathrm{C}$ with a hold time of $3 \mathrm{~min}$. This cycle was repeated twice at 800 $\mathrm{W}$ of applied power.

Once the samples were digested, the content of each Teflon tube was transferred into a $50 \mathrm{~mL}$ volumetric flask and filled with ultra-pure water before the analyses in the AAS or ICP-MS were performed.

The analysis for the most concentrated elements (i.e., $\mathrm{Ca}, \mathrm{K}, \mathrm{Na}, \mathrm{Mg}, \mathrm{Cu}, \mathrm{Mn}, \mathrm{Fe}$ and $\mathrm{Zn}$ ) was completed in an AAS (280FS AA, Agilent Technologies), whereas trace metal ions (i.e., $\mathrm{Al}, \mathrm{Cd}$, $\mathrm{Cr}, \mathrm{Hg}, \mathrm{Ni}, \mathrm{Pb}, \mathrm{Se}, \mathrm{Sn}$ and $\mathrm{Co}$ ) were analyzed with an ICP-MS (7700x, Agilent Technologies), using argon gas to form the plasma for the instrument. The ICP-MS was equipped with an ASX 500-CETAC auto-sampler, a micro-concentric nebulizer, nickel cones, and a peristaltic sample delivery pump. The operation conditions of the AAS and ICP-MS are detailed in Table 2.

Table 2. Instrumental conditions for atomic absorption spectroscopy (AAS) and inductively coupled plasma-mass spectrometry (ICP-MS) analyses.

\begin{tabular}{lc}
\hline Parameters & Value \\
\hline AAS & \\
Flame & Air/acetylene \\
Air flow $\left(\mathrm{L} \mathrm{min}^{-1}\right)$ & 13.50 \\
Flow acetylene $\left(\mathrm{L} \mathrm{min}^{-1}\right)$ & 2.00 \\
Burner height $(\mathrm{mm})$ & 13.5 \\
Slit width $(\mathrm{nm})$ & $0.2-1.0$ \\
Lamp current $(\mathrm{mA})$ & $4-10$ \\
Metals & Wavelength $(\mathrm{nm})$ \\
K & 766.5 \\
Na & 589.0 \\
Ca & 422.7 \\
Mg & 285.2 \\
Cu & 324.8 \\
Zn & 213.9 \\
Fe & 248.3 \\
Mn & 279.5 \\
ICP-MS & \\
RF generator frequency $(\mathrm{MHz})$ & 27 \\
RF applied power $(\mathrm{W})$ & 1550 \\
Plasma gas flow rate $\left(\mathrm{L} \mathrm{min}{ }^{-1}\right)$ & 15 \\
Auxiliary gas flow rate $(\mathrm{L} \mathrm{min}-1)$ & 0.9 \\
Nebulizer gas flow rate $\left(\mathrm{L} \mathrm{min}{ }^{-1}\right)$ & 1.03 \\
Stabilization delay $(\mathrm{s})$ & 10 \\
Internal standards & Sc and Er \\
Number of masses & 32 \\
\hline
\end{tabular}


Each wine bottle was sampled, pre-treated, and analyzed three times. Each of the analytical readings was also repeated three times.

\section{Data analysis}

The metal content of the samples was analyzed using descriptive statistics (i.e., mean, range, standard deviation, and median) and presented as the average of all the wine samples, or separated into white and red wine subgroups.

One-way analysis of variance (ANOVA), followed by a post hoc Tukey test, was conducted for each element, looking for metals that could allow for the grouping of samples according to their place of origin $(p \leq 0.05)$. Additionally, principal component analysis (PCA) was used to identify the main elements that explain the data variance, whereas linear discriminant analysis (LDA) was used for sample discrimination (Angus et al. 2006; Laurie et al., 2010; Coetzee et al. 2014). These latter analyses (i.e., PCA and LDA) were performed separately for white and red wines, excluding the samples representing the Central Valley ( $n=30$ white and 70 red wine samples). These analyses were done at a subregional level to avoid collinearity between samples of different hierarchical classification.

To avoid attributing subregional differences to wines whose metal profiles could have been influenced by varietal disparities, multivariate analyses were conducted only with metals that did not show significant differences according to varieties (e.g., $\mathrm{Zn}, \mathrm{Ca}, \mathrm{Na}, \mathrm{Mn}, \mathrm{Fe}, \mathrm{Cu}, \mathrm{K}, \mathrm{Al}, \mathrm{Sn}$, $\mathrm{Pb}, \mathrm{Ni}$, and $\mathrm{Cr}$ in white wine and $\mathrm{Zn}, \mathrm{Ca}, \mathrm{Na}, \mathrm{Mn}$, $\mathrm{Mg}, \mathrm{Fe}, \mathrm{Cu}, \mathrm{K}, \mathrm{Al}, \mathrm{Sn}, \mathrm{Ni}$, and $\mathrm{Cr}$ in red wine) (Table b, supplemental information).

In all cases, the statistical analyses were performed using Statgraphics Centurion XV (Statpoint technologies, Warrenton, VA, USA), and graphical representations were made using Sigma-Plot version 12 (Systat Software Inc. Chicago, IL, USA).

\section{Results and Discussion}

Table 3 shows a summary of the identified concentrations of the main metal elements. As expected, $\mathrm{K}$ was the metal with the highest average concentration, followed by $\mathrm{Mg}, \mathrm{Ca}$ and $\mathrm{Na}$. The least prevalent metal elements, with concentrations below $0.001 \mathrm{mg} \mathrm{L}^{-1}$, were $\mathrm{Cd}, \mathrm{Hg}$, $\mathrm{Co}$, Se, and $\mathrm{Pb}$ (data not included). These results agree with previously published data for other wines and regions, from which the following concentration ranges have been reported: K, 125 - $2040 \mathrm{mg} \mathrm{L}^{-1}$; Ca, 50 - 300 $\mathrm{mg} \mathrm{L}^{-1}$; Na, 3 - $279 \mathrm{mg} \mathrm{L}^{-1}$; Mg, 32 - $245 \mathrm{mg} \mathrm{L}^{-1}$; Fe, 0.6 - $16.1 \mathrm{mg} \mathrm{L}^{-1} ; \mathrm{Zn}, 0.07$ - $5.6 \mathrm{mg} \mathrm{L}^{-1} ; \mathrm{Mn}, 2.4$ - 7.5 $\mathrm{mg} \mathrm{L}^{-1} ; \mathrm{Cd}, 0.00-0.03 \mathrm{mg} \mathrm{L}^{-1} ; \mathrm{Cu}, 0.02-2.41 \mathrm{mg}$ $\mathrm{L}^{-1} ; \mathrm{Pb}, 0.001-0.62 \mathrm{mg} \mathrm{L}^{-1} ; \mathrm{Co}, 0.004-0.04 \mathrm{mg}$ $\mathrm{L}^{-1} ; \mathrm{Cr}, 0.002$ - $0.23 \mathrm{mg} \mathrm{L}^{-1} ; \mathrm{Ni}, 0.00$ - $0.13 \mathrm{mg} \mathrm{L}^{-1}$; Sn, n.d - $0.003 \mathrm{mg} \mathrm{L}^{-1}$; Se, $0.0003-0.004 \mathrm{mg} \mathrm{L}^{-1}$, etc. (Ough et al., 1982; Iglesias et al., 2007; Pohl, 2007; Hopfer et al., 2015).

Red wines have statistically higher concentrations of $\mathrm{K}, \mathrm{Mg}, \mathrm{Mn}, \mathrm{Fe}$, and $\mathrm{Cr}$ when compared with white wines, where $\mathrm{Ca}$ and $\mathrm{Na}$ were more prevalent. The former is mainly explained by winemaking differences such as skin extraction during red wine fermentation (Serapinas et al., 2008; Vázquez et al., 2013). For example, $\mathrm{K}$ is highly concentrated in the pericarp of the fruit, and long maceration periods, such as those occurring during red wine fermentation, result in an increased concentration of this metal element (Storey, 1987; Iland and Coombe, 1988). On the other hand, an elevated concentration of $\mathrm{Na}$ in white wines has been attributed to the edaphoclimatic characteristics of certain areas in which these wines are produced, such as a limited rainfall and accumulation of this element in the soil (González et al., 1996; Laurie et al., 2010).

\section{Content of metals and wine discrimination} according to geographic area

Statistical differences were observed for several of the metals analyzed $(p \leq 0.05)$ when the samples 
Table 3. Summary of the concentration of metallic elements for the selected Chilean wine samples.

\begin{tabular}{|c|c|c|c|c|c|c|c|c|c|c|c|c|c|}
\hline \multicolumn{14}{|c|}{ Ion concentration $\left(\mathrm{mg} \mathrm{L}^{-1}\right)$} \\
\hline & $\mathrm{Ca}$ & $\mathrm{Mg}$ & $\mathrm{K}$ & $\mathrm{Na}$ & $\mathrm{Mn}$ & $\mathrm{Cu}$ & $\mathrm{Zn}$ & $\mathrm{Fe}$ & $\mathrm{Al}$ & $\mathrm{Cr}$ & $\mathrm{Ni}$ & $\mathrm{Pb}$ & $\mathrm{Sn}$ \\
\hline \multicolumn{14}{|c|}{ All wines $(n=130)$} \\
\hline Mean & 52 & 92 & 788 & 15 & 1.4 & 0.4 & 0.7 & 2.08 & 1.2 & 0.013 & 0.007 & 0.03 & 0.03 \\
\hline SD & 12 & 18 & 220 & 9 & 0.6 & 0.3 & 0.4 & 0.99 & 0.9 & 0.008 & 0.005 & 0.02 & 0.02 \\
\hline Range & $29-97$ & $38-145$ & $254-1251$ & $3-65$ & $0.01-3.1$ & $0.005-1.3$ & $0.01-4.1$ & $0.19-5.89$ & $0.008-6.5$ & $0.003-0.07$ & $0.001-0.03$ & $0.003-0.86$ & $0.01-0.32$ \\
\hline Median & 51 & 92 & 817 & 12 & 1.4 & 0.3 & 0.7 & 1.94 & 0.95 & 0.01 & 0.01 & 0.01 & 0.01 \\
\hline \multicolumn{14}{|c|}{ White wines $(n=39)$} \\
\hline Mean & 56 & 78 & 530 & 22 & 1.2 & 0.4 & 0.8 & 1.2 & 1.2 & 0.013 & 0.005 & 0.03 & 0.03 \\
\hline SD & 13 & 18 & 127 & 10 & 0.5 & 0.3 & 0.6 & 0.6 & 0.7 & 0.004 & 0.004 & 0.02 & 0.02 \\
\hline Range & $33-94$ & $38-116$ & $254-749$ & $5-65$ & $0.01-1.96$ & $0.1-1$ & $0.01-4.1$ & $0.19-2.8$ & $0.007-3.6$ & $0.003-0.03$ & $0.001-0.02$ & $0.003-0.25$ & $0.01-0.28$ \\
\hline Median & 55 & 80 & 549 & 20 & 1.3 & 0.4 & 0.7 & 1.2 & 1.2 & 0.01 & 0.01 & 0.02 & 0.01 \\
\hline \multicolumn{14}{|c|}{ Red wines $(n=91)$} \\
\hline Mean & 50 & 98 & 899 & 11 & 1.5 & 0.4 & 0.7 & 2.4 & 1.2 & 0.021 & 0.007 & 0.04 & 0.03 \\
\hline SD & 11 & 14 & 145 & 6 & 0.6 & 0.3 & 0.3 & 0.9 & 1.00 & 0.006 & 0.006 & 0.03 & 0.02 \\
\hline Range & $29-97$ & $65-145$ & $515-1276$ & $3-42$ & $0.37-3.1$ & $0.005-1.3$ & $0.18-1.4$ & $0.88-5$ & $0.008-6.5$ & $0.003-0.07$ & $0.001-0.03$ & $0.003-0.86$ & $0.01-0.32$ \\
\hline Median & 49 & 96 & 910 & 10 & 1.5 & 0.3 & 0.6 & 2.4 & 0.9 & 0.01 & 0.01 & 0.01 & 0.01 \\
\hline
\end{tabular}

were grouped and compared based on the location declared on their labels. For example, Maipo wines (predominantly producing Cabernet Sauvignon) had a higher concentration of $\mathrm{K}$ when compared with Aconcagua, Casablanca (predominantly producing white wines), and Curicó valleys. Colchagua and Maipo wines had more Mn than Curicó samples. Casablanca wines had more $\mathrm{Na}$ than most of the other wines. Colchagua wines had more $\mathrm{Zn}$ than Lontué and Loncomilla samples. Metal elements such as $\mathrm{Ca}, \mathrm{Cu}, \mathrm{Fe}, \mathrm{Al}, \mathrm{Ni}$, Sn and $\mathrm{Pb}$ did not show significant differences among the wines compared from different geographic areas (Figure a, supplemental information).

Geological and climatic differences seemed to be decisive in the concentration of some of these elements (Zou et al., 2012; Coetzee et al., 2014; Paneque et al., 2017). For example, a high $\mathrm{Na}$ content in Casablanca could be due to the presence of saline ground water or sea winds that contain salty water could reach some of these vineyards (Pohl, 2007; Blume et al., 2015). This could be exacerbated by the limited rainfall experienced in recent years; this is similar to semi-arid areas where these types of cations accumulate in the soil due to the scarcity of rainfall (González et al., 1996; Sierra et al., 2001).

\section{Principal component analysis}

Given the differences observed in the concentration of metals among the geographic areas studied, PCA was performed to identify the main vectors that explain the variability for these samples. An initial multivariate analysis was carried out for data reduction, allowing for the removal of elements that had strong linear correlations (Hopfer et al., 2015). Metal elements that showed significant differences in their concentration between white and red varieties were also excluded from the multivariate analyses ( $\mathrm{Mg}$ in case of white varieties, and $\mathrm{Pb}$ in case of red varieties), thus limiting the influence of varietal differences on the geographic area discrimination.

When a PCA was performed comparing red and white wines, $84.50 \%$ of the variability was explained by the first two principal components. In this case, the variability was mainly explained by the content of $\mathrm{Na}$ and the concentration of 
$\mathrm{Mg}$ and $\mathrm{K}$ (Figure 2a). Consequently, further analyses were performed separately for white and red wines; values for the first two principal components reached $95.28 \%$ for white wines and $77.69 \%$ for reds (Figure $2 b$ and c). The main components that explained the variability among groups of samples were clearly identified in white wines but not as much in reds, where a higher degree of overlapping among neighboring subregions and zones (and even areas) was observed (e.g., Rapel, Maule, San Javier, Loncomilla). This finding was probably because Maule is the largest viticultural area in Chile (Figure 1) with approximately $30,296.1 \mathrm{Km}^{2}$ that spans from the coast to the Andes (ODEPA 2016).

\section{Linear Discriminant Analysis}

Given the results obtained by PCA, linear discriminant analysis (LDA) was used to divide the sample space, to separate the best possible subgroups, and to discriminate wines according to geographic area. As before, red and white samples were treated separately.
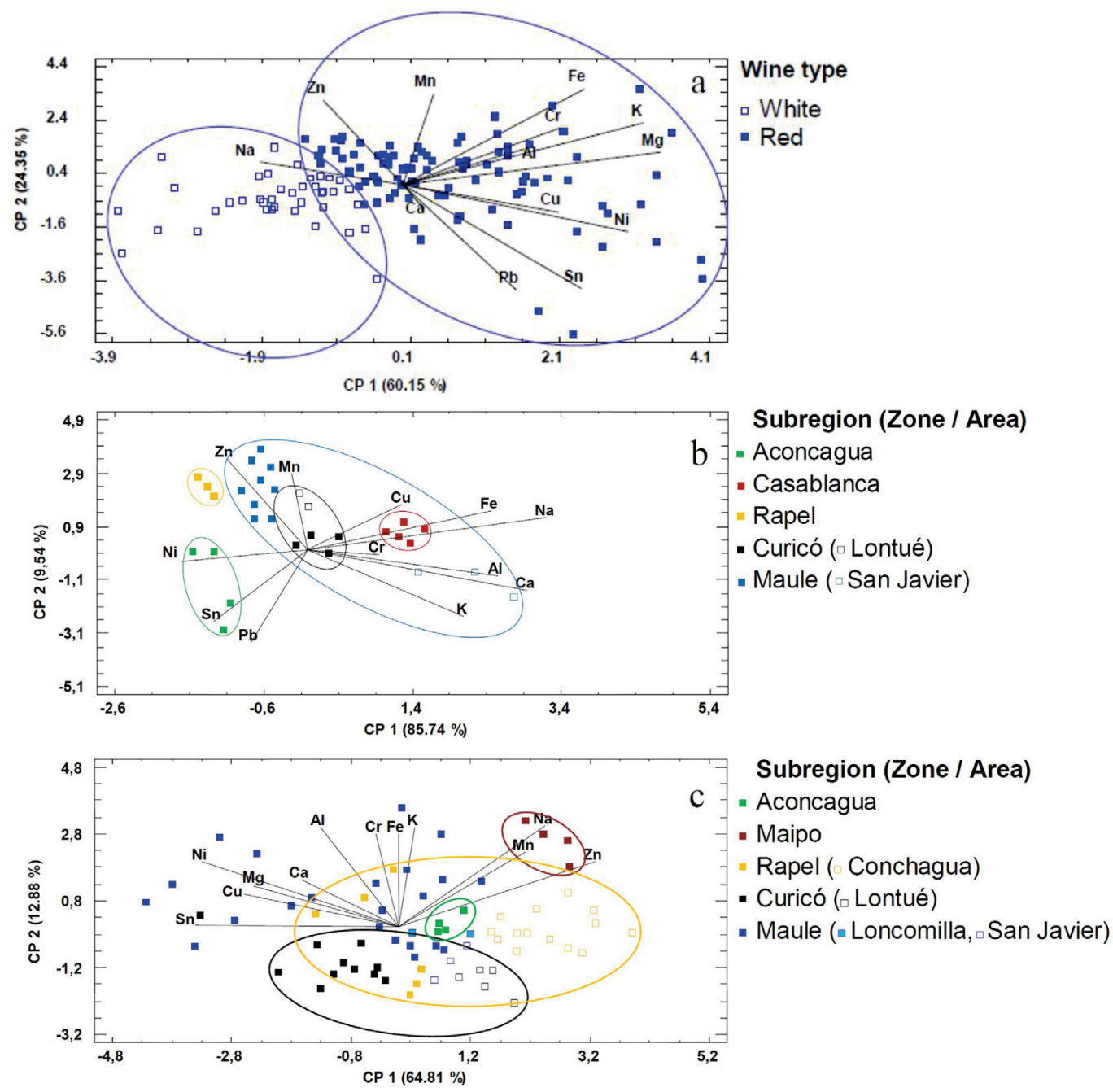

Figure 2. Score plot of the first two principal components (principal component analysis, PCA) of (a) 130 Chilean wine samples grouped by the type of wine, (b) 39 white wines grouped by geographic origin, and (c) 91 red wines grouped by geographic origin. 
In the case of white wines, the magnitudes of twelve independent variables (i.e., $\mathrm{Ca}, \mathrm{K}, \mathrm{Cu}, \mathrm{Na}$, $\mathrm{Mn}, \mathrm{Fe}, \mathrm{Zn}, \mathrm{Al}, \mathrm{Cr}, \mathrm{Ni}, \mathrm{Sn}$ and $\mathrm{Pb}$ ) were used as predictors to discriminate thirty wine samples according to their places of origin. The model allowed for a $96.9 \%$ discrimination of white wines according to their places of origin (Figure 3a). As shown in Figure 3a, the samples representing the five subregions studied were well grouped. As indicated before, the wines labeled under the Central Valley denomination were eliminated from these analyses because they include wines containing grapes may have come from different geographic origins. A minimum of $75 \%$ of the grapes should come from a specific region to label a wine from a specific place in Chile (Ministerio de Agricultura, 1995).

In the case of red wines, twelve predictor variables (Ca, K, Cu, Na, Mn, Fe, Zn, Al, Cr, Ni, Sn and $\mathrm{Mg}$ ) were used to discriminate seventy samples according to their place of origin. In this case, the model allowed for $79.43 \%$ sample discrimination
(Figure 3b). The wine samples representing the Maule subregion had the highest variability, as they comprise a high diversity of mesoclimates and soils. Maule valley is the largest viticultural origin in Chile with approximately 53,497 ha, representing $36.7 \%$ of the national surface area of vineyards dedicated to winemaking (ODEPA, 2016).

As indicated elsewhere (Zou et al., 2012; Versari et al., 2014), the metal composition of wines is a useful way to characterize and discriminate wines according to their geographic area; they largely reflect the composition of metals in the soil and water of the places in which the grapes are grown (Pohl, 2007). The limitations of this technique include the purity of the wines analyzed, variations in winemaking style, the use of winemaking aids, yeast culture and vinification practices, etc. (Pohl, 2007; Rossano et al., 2007; Álvarez et al., 2007; Hopfer et al., 2015). In this case, the samples selected had a limited range of prices and winemaking styles, thus allowing for

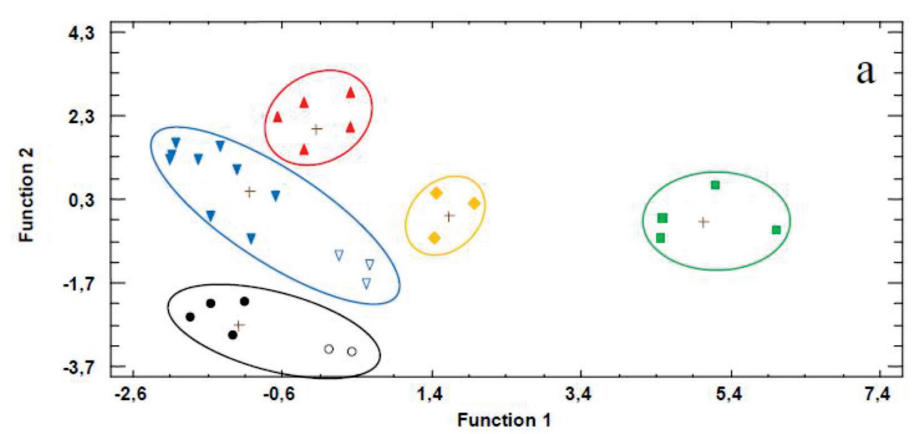

Subregion (Zone / Area)

- Aconcagua

- Casablanca

- Rapel

- Curicó (॰Lontué)

- Maule ( $\nabla$ San Javier)

+ Centroids

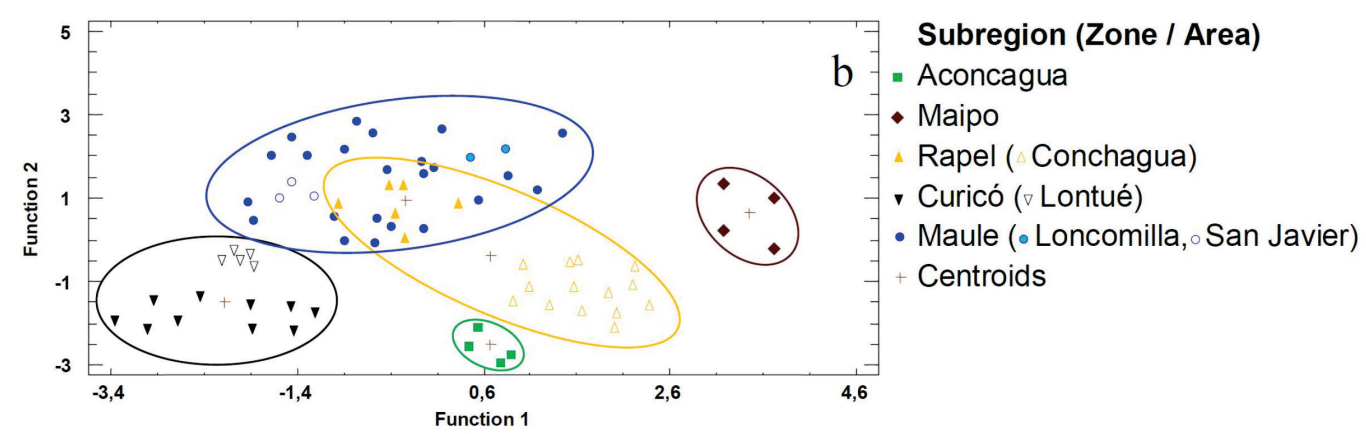

Figure 3. Scatter plot of the linear discriminant functions for (a) 39 samples of white wine analyzed according the region of origin, and (b) 91 samples of red wine analyzed according the region of origin. 
a good degree of geographic area discrimination. A more complete study that allows for the determination of the origin of a larger group of wines, the influence of their purity (i.e., unblended vs. blended), production and storage practices, and a greater number of samples per zone is necessary.

The main conclusions are as follows. All metal concentrations were within the ranges previously reported for wines from other regions. As expected, red wines had a higher concentration of $\mathrm{K}, \mathrm{Mg}$ and Fe compared to white wines, in which $\mathrm{Na}, \mathrm{Ca}$, and Zn were particularly concentrated. The exploratory data analysis conducted with PCA allowed for the identification of the main components explaining the variability among samples. In the case of white wines, the first two main components explained $95.28 \%$ of the variability, whereas in red wines only $77.69 \%$ of the variability was explained by the first two principal components. On the other hand, LDA analysis allowed for a good degree of discrimination by geographic area for white (i.e., $96.9 \%$ ) and red wines (i.e., 79.43\%). To the best of our knowledge, this is the first time that the content of a large number of metallic elements in Chilean wines has been described and used to discriminate wine origins. No previous attempts to discriminate Chilean wine areas, based on a broad range of multi-elemental compositional data, have been published.

\section{Acknowledgments}

This research was sponsored by CONICYT through FONDECYT grants 3140293 and 1150725. Support from the Chilean Institute of Public Health (ISP) and Universidad de Talca's Soils and Crops Technology Center (CTSYC) is also appreciated.

\title{
Resumen
}

\begin{abstract}
Y. Mirabal-Gallardo, M. A. Caroca-Herrera, L. Muñoz, M. Meneses, y V. F. Laurie. Análisis y diferenciación de vinos chilenos empleando su composición de elementos metálicos y técnicas de estadística multivariada. 2018. Cien. Inv. Agr. 45(2): 181-191. La concentración de diecisiete elementos metálicos se analizó en 130 muestras comerciales de vinos chilenos, utilizando espectroscopía de absorción atómica de llama (AAS) y espectrometría de masas con plasma acoplado inductivamente (ICP-MS). Los elementos analizados estuvieron dentro de los rangos de concentración habituales reportados previamente en otras regiones vitivinícolas del mundo; por ejemplo: Fe, 2,08 \pm 0,99 mg L-1; Zn, 0,71 \pm 0,44 mg L-1; K, $788 \pm 219$ mg L-1; $\mathrm{Na}, 14,62 \pm 8,6 \mathrm{mg} \mathrm{L}-1$. Cuando se comparó el contenido metálico de las muestras entre áreas geográficas, se observaron diferencias significativas en la concentración de $\mathrm{K}, \mathrm{Na}, \mathrm{Mn}, \mathrm{Mg}, \mathrm{Zn}$ y $\mathrm{Cr}(\mathrm{p} \leq 0.05)$. Además, los análisis de componentes principales y análisis discriminación lineal se utilizaron para discriminar los vinos de acuerdo con el área geográfica, obteniendo ajustes por encima del $90 \%$ para los vinos blancos y más del $70 \%$ para los vinos tintos.
\end{abstract}

Palabras clave: AAS, clasificación, elemento, estadística multivariada, ICP-MS, metal, vino.

\section{References}

Aceto, M., E. Robotti, M. Oddone, M. Baldizzone, G. Bonifacino, G. Bezzo, R. Di Stefano, F. Gosetti, E. Mazzucco, M. Manfredi, and E. Marengo. 2013. A traceability study on the Moscato wine chain. Food Chemistry. 138:1914-1922.
Alkis, I.M., S. Öz, A. Atakol, N. Yilmaz, R.E. Anli, and O. Atakol. 2014. Investigation of heavy metal concentrations in some Turkish wines. Journal of Food Composition and Analysis. 33:105-110.

Almeida, C.M., and M.T. Vasconcelos. 2003. Multielement composition of wines and their precursors including provenance soil and their poten- 
tialities as fingerprints of wine origin. Journal of Agricultural and Food Chemistry. 51:4788-4798.

Álvarez, M., I.M. Moreno, A.M. Jos, A.M. Cameán, and A.G. González. G. 2007. Study of mineral profile of Montilla-Moriles "fino" wines using inductively coupled plasma atomic emission spectrometry methods. Journal of Food Composition and Analysis. 20:391-395.

Angus, N.S., T.J. O'Keeffe, K.R. Stuart, and G.M. Miskelly. 2006. Regional classification of New Zealand red wines using inductively-coupled plasma-mass spectrometry (ICP-MS). Australian Journal of Grape and Wine Research. 12:170-176.

Arvanitoyannis, I.S., M.N. Katsota, E.P. Psarra, E.H. Soufleros, and S. Kallithraka. 1999. Application of quality control methods for assessing wine authenticity: Use of multivariate analysis (chemometrics). Trends in Food Science \& Technology. 10: 321-336.

Blume, H.P., G.W. Brümmer, H. Fleige, R. Horn, E. Kandeler, I.K. Knabner, R. Kretzschmar, K. Stahr, and B.M. Wilke. 2015. Scheffer/ Schachtschabel Soil Science. Springer Berlin Heidelberg. pp 620.

Castiñeira, M.D., I. Feldmann, N. Jakubowski, and J.T. Andersson. 2004. Classification of German white wines with certified brand of origin by multielement quantitation and pattern recognition techniques. Journal of Agricultural and Food Chemistry. 52:2962-2974.

Catarino, S., M. Madeira, F. Monteiro, F. Rocha, A.S. Curvelo, and R.B. Sousa. 2007. Effect of bentonite characteristics on the elemental composition of wine. Journal of Agricultural and Food Chemistry. 56:158-165.

Coetzee, P.P., F.E. Steffens, R.J. Eiselen, O.P. Augustyn, L. Balcaen, and F. Vanhaecke. 2005. Multi-element analysis of South African wines by ICP-MS and their classification according to geographical origin. Journal of Agricultural and Food Chemistry. 53:5060-5066.

Coetzee, P.P., and F. Vanhaecke. 2005. Classifying wine according to geographical origin via quadrupole based ICP-mass spectrometry measure- ments of boron isotope ratios. Analytical and Bioanalytical Chemistry. 383:977-984.

Coetzee, P.P., F.P. Jaarsveld, and F. Vanhaecke. 2014. Intraregional classification of wine via ICPMS elemental fingerprinting, Food Chemistry. 164:485-492.

González, G.H., A.T. Hardisson, and J.J. Arias. 1996. Quantity of K, Ca, $\mathrm{Na}, \mathrm{Mg}, \mathrm{Fe}, \mathrm{Cu}, \mathrm{Pb}$, $\mathrm{Zn}$ and ashes in DOC Tacoronte-Acentejo (Canary Islands, Spain) musts and wines. Zeitschrift für Lebensmittel-Untersuchung und Forschung. 203:517-521.

Grindlay, G., J. Mora, L. Gras, and M.T.C. de LoosVollebregt. 2009. Ultratrace determination of $\mathrm{Pb}$, Se and As in wine samples by electrothermal vaporization inductively coupled plasma mass spectrometry. Analytica Chimica Acta. 652:154-160.

Hopfer, H., J. Nelson, T.S. Collins, H. Heymann, and S.E. Ebeler. 2015. The combined impact of vineyard origin and processing winery on the elemental profile of red wines. Food Chemistry. 172:486-496.

Iglesias, M., E. Besalú, and E. Anticó. 2007. Internal standardization-atomic spectrometry and geographical pattern recognition techniques for the multielement analysis and classification of catalonian red wines. Journal of Agricultural and Food Chemistry. 55:219-225.

Iland, P.G., and B.G. Coombe. 1988. Malate, tartrate, potassium, and sodium in flesh and skin of Shiraz grapes during Ripening: Concentration and compartmentation. American Journal of Enology and Viticulture. 39:71-76.

Laurie, V.F., E. Villagra, J. Tapia, J.E.S. Sarkis, and M.A. Hortellani. 2010. Analysis of major metallic elements in Chilean wines by atomic absorption spectroscopy. Ciencia e Investigación Agraria. 37:77-85.

Ministerio de Agricultura, 1995. Decreto 464; 26mayo-1995. Establece zonificación vitícola y fija normas para su utilización.

ODEPA. 2016. Ficha Nacional Información nacional. 2016. http://www.odepa.cl/wp-content/ files_mf/1483121915Ficha Nacional diciembre. pdf. (accessed Mar 15,2017). 
Ough, C.S., E.A. Crowell, and J. Benz 1982. Metal content of California wines. Journal of Food Science. 47:825-828.

Paneque, P., M.L. Morales, P. Burgos, L. Ponce, and R.M. Callejon. 2017. Elemental characterisation of Andalusian wine vinegars with protected designation of origin by ICP-OES and chemometric approach. Food Control. 75:203-210.

Pohl, P. 2007. What do metals tell us about wine? Trends in Analytical Chemistry. 26:941-949.

Rossano, E.C., Z. Szilgyi, A. Malorni, and G. Pocsfalvi. 2007. Influence of winemaking practices on the concentration of rare earth elements in white wines studied by inductively coupled plasma mass spectrometry. Journal of Agricultural and Food Chemistry. 55:311-317.

Serapinas, P., P.R. Venskutonis, V. Aninkevicius, Z. Ezerinskis, A. Galdikas, and V. Juzikiene. 2008. Step by step approach to multi-element data analysis in testing the provenance of wines. Food Chemistry. 107:1652-1660.

Sierra, C., R. Césped, and A. Osorio. 2001. Caracterización de la salinidad de los suelos y aguas del Valle del río Copiapó. Boletín INIA - Instituto de Investigaciones Agropecuarias. $\mathrm{N}^{\circ} 70$.
Storey, R. 1987. Potassium localization in the grape berry pericarp by energy-dispersive X-Ray microanalysis. American Journal of Enology and Viticulture. 38:301-309.

Tariba, B. 2011. Metals in wine: Impact on wine quality and health outcomes. Biological Trace Element Research. 144:143-156.

Vázquez, E.S., S.R. Segade, and E.F. Gómez. 2013. Incidence of the winemaking technique on metal content and phenolic composition of red wines. International Journal of Food Properties. 16:622-633.

Versari, A., V.F. Laurie, A. Ricci, L. Laghi, and G.P. Parpinello. 2014. Progress in authentication, typification and traceability of grapes and wines by chemometric approaches. Food Research International. 60:2-18.

Zou, J.F., Z.X. Peng, H.J. Du, C.Q. Duan, M.J. Reeves, and Q.H. Pan. 2012. Elemental patterns of wines, grapes, and vineyard soils from Chinese wine-producing regions and their association. American Journal of Enology and Viticulture. 63:232-240. 